\title{
Mollenhauer and the pedagogical relation: A general pedagogic from the margins
}

\author{
Tone Saevi, NLA University College, School of Pedagogic, Norway \\ ts@nla.no
}

\section{Introduction}

My interest in Forgotten Connections: On Culture and Upbringing, was evoked in the early 90 's when I as a graduate student read my supervisor, Stein Wivestad's, preliminary Norwegian translation of the first chapters. Some years later, as a teacher of undergraduate students in pedagogic I introduced Klaus Mollenhauer's almost impenetrably complex thoughts and questions through the indirect intermediary of feature film and fictional literature. Over the years, it became more and more obvious to me, and made sense constantly in new ways, that the experiential material - film and fictional stories - indeed as Mollenhauer suggested, were not simply a means to illustrate compelling but hard-to-get-at reflections, concepts and theoretical considerations. On the contrary, the experiential examples presented and represented "real" and perceptible human life, where every pedagogical question has its source and purpose. Then, twelve years ago, when I was taught hermeneutic phenomenology by Max van Manen, and I gradually found ways to amalgamate to pedagogic a methodical phenomenological reduction and the vocative writing style of this approach, I discovered anew what I understood as Mollenhauer's pedagogical vision. I understood that his rich historical experiential material - autobiographical excerpts, childhood memories, teachers' examples, paintings and woodcuts - what he called the elementary material for pedagogical insight, indeed possessed qualities potentially open to phenomenological exploration. Phenomenology, as interpreted by van Manen and pedagogic as interpreted by Mollenhauer met in their shared focus on the lived experience of the encounter between the older and the newer generation. This is how Mollenhauer says it:

These [the stories of concrete relational situations] aren't formal scholarly descriptions of Bildsamkeit; they instead tell of particular situations; situations where Bildsamkeit is recognizable. [...] They are in this sense like legal precedents in law and case histories in psychoanalysis. The entire enterprise of pedagogy is in the final analysis built on and driven by such experiences and narratives. (Mollenhauer, 2014, p. 74)

In addition to being descriptions of particular situations where the child's Bildsamkeit - or, latent potential for human subjectivity - comes to expression, Mollenhauer emphasized that these descriptions reflect and expose the adult (often unaware) understanding of the relation he or she has with the child (Mollenhauer 1996, p. 93). The concrete stories told by adults about their relation to children were not primarily useful didactical material for curriculum planning or tools for someone's interest in an educational project, but they were life itself, incorporated and incarnated in the adult in the cultural condition. Mollenhauer's focus on the concrete descriptions of pedagogical relationships - historical, contemporary, real, fictional combined with methodic ways provided by phenomenology, at that time were, to me, seminal insights. As I framed it recently: "The formulation of educational aims of purpose and content presupposes an experiential validation for the educational moral expressed in these aims and thus weaves theory and practice together in the meaning of the human experience" (Saevi 
2015 , p. 6). The concrete descriptions of pedagogical relationships have become the premise for my understanding of pedagogic, and my practical and theoretical sources come from and via the experiential examples.

\section{Mollenhauer's Choice of Experiential Examples}

On the very first page of his book Forgotten Connections: On Culture and Upbringing, Mollenhauer brings to our attention the question of children's exposedness and dependence of adults, and by the same token he withholds calculated or even desired results in education. He refers to renowned educational documents in our culture, such as Elias Canetti's childhood biography and Pestalozzi's descriptive reflections of his failed educational project in Stans, and observes that they in "many instances, $[\ldots]$ are not success stories" $(2014$, p. 1). Despite good intentions, which most parents and teachers claim to have, upbringing and education is at once a "process of broadening and enrichment as well as narrowing and impoverishment a question of what might have been" (p. 2). The quality of more than one option in pedagogic comes from what Kafka speaks of as "the magnitude of the matter" (p. 3); this massive conglomeration of matters, acts, recollections and implications that constitute and come out of the life-experiences of each individual human being. There are alternatives to the concrete upbringing as it was back in childhood, and alternatives to the ways individuals remember and express their upbringing, as well as to the ways they make sense of childhood recollections. A central question to Mollenhauer is what we, as adults, by certainty can justify when we accurately and honestly try to remember and interpret our own childhood memories or the way we brought up our own children. Moreover, and perhaps more importunate is the question of how we actually articulate our memories, opinions and insights. Mollenhauer addresses the very quality of the language with which we speak of children and upbringing. The language of each person has threads back to childhood; to the language of his or her upbringing, to the person or persons who gave meaning to the moments in and of this particular upbringing, and of course, to the self, the child who was brought up. Thus, when encountering a child in a current pedagogic situation we do not only encounter this particular present child, but also "the child within us, before us and with us," as Lippitz perceives (1986). Education understood as an existential relation to self and other, framed by the present as well as the past and future of the persons, requires an anthropological and experiential onto-epistemological interest in the meaning of educational events. The relation that is the pedagogic link between the older and the younger generation, in particular is concerned about how the situation is and was experienced by the child or young person. In this way, pedagogic contradicts the idea of education as curriculum planning spelled out as educational psychology, sociology, philosophy or any other foundational discipline, and offers an existential moral-laden and democratic alternative, with the pedagogical relation as its fulcrum (Saevi 2011). How then does the relation between adult and child, teacher and pupil look in Mollenhauer's sketch of a general pedagogic, and how can we understand his descriptions?

\section{Two Examples from the Margins}

In Forgotten Connections Mollenhauer thoroughly addresses general pedagogic questions from the experiential perspective of children and artists at the educational margins. These experiences commonly would be classified as adjustment difficulties or learning disabilities, and placed within special education. This rather unusual approach to general pedagogic spoke to me the first time I read the text and more so today facing the pedagogic relationship systematically calculated through the teacher's psychological superiority and identified in 
epistemological outcomes (Saevi, 2015). What does it mean to the pedagogic relation and to the child if general pedagogic questions are seen in light of experiential material of pedagogical situations from the margins? Among Mollenhauer's many examples, I pick Jürgen Jegge, himself a teacher, who describes his relationship to Heini (or little Henry) in this episode:

Little Henry (...) was unable to express wishes... For example when he came to visit, if I were to ask him whether he'd like tea or juice, he would answer, "I don't know", or "I don't care". This kind of response was not the result of his not knowing the difference between tea and juice, but instead was due to his inability to articulate his own needs and desires. Ever since I'd known little Henry I'd tried to help him articulate his desires in such situations. So in this case, I said: "You've only to try to imagine a cup of tea - linden blossom flavor, warm, sweet and so on; and now imagine a glass of juice - raspberry flavor, cold, with ice in it. Which of the two would you rather have? Then, giving me a totally helpless look, he said: "Which do you have more of?" He didn't say this out of fear that he wouldn't be able to get what he wanted. He was instead trying to figure out what I wanted him to want. This was even clearer when I sent him shopping. For example, I would say "Go get me a chocolate bar." No sooner after I asked him, he would immediately want to know, "Which kind?" And if I said to him, "Any kind," he would rest until I told him exactly which kind of chocolate to get". (Jegge 1977, p. 62)

The example can be read pedagogically in a variety of ways. I will confine myself to two pedagogical qualities required for pedagogic to be pedagogical (rather than for example psychological, philosophical or managerial). What strikes me is the direct and serious way that the teacher tells this story. The episode carries weight for the teacher. The situation is important to him, not as an example of how well he as a teacher managed difficult children, or to justify how he acted in a demanding situation. In fact, he does not suggest any solution, or even point to a problem. He simply tells the story so that we, the readers, might get a pathic insight in the situation. Then, his pedagogical respect for Heini prevents him from elevating himself on behalf of the child - to even consider his agenda more important than the boy's. They are both there in each of their ways as adult and child, and that is about it.

Another description might illuminate some other pedagogical features recognizable in Mollenhauer's choice of examples. This time he picks a situation from Bonneuil, a children's psychiatric hospital in Paris, described by Maud Mannoni (1978) in her book Ein Ort zum Leben.

Teacher: "How many fingers do you have?"

Didier: "Just a sec. Hmmm...one, two, three, four. Four."

"And how many do I have?"

(Didier counts) "Five"

"Does everyone have the same number of fingers?"

"Yup."

"So how many fingers does Charles have?"

"Five."

"And you?"

"I just told you."

"But how many was that?"

"Oh come on, four!" 
"But I have five, right?"

Yeah, but I have still got fewer.” (Mollenhauer 2014, p. 90)

The story of Didier and his teacher counting fingers addresses the pedagogical point that telling what happened is the origin of pedagogic insight, as well as a description of an implicit possibility of pedagogic defeat. We, as readers, spontaneously understand something. We relate the meaning of the episode to our own experience, to our own practice, or to what might have been our own practice. We are urged to reflect on who Didier is, and who his teacher is. How is their relation? What did they do, and what would I have done? The story is the teacher's self-reflexive description, but it also speaks to my self. The story addresses me as a pedagogical possibility. It occurs to me that the "border" experiences that Mollenhauer chooses are not just occasional episodes, and the persons inhabiting them are not just unsuccessful young persons requiring extraordinary pedagogic action. In fact, according to Mollenhauer's pedagogical descriptions all children are extraordinary. His stories from the margins are examples of the profound existential unavailability of every child and consequently the aporetic impossibility of pedagogic. By presenting to us the case of Kaspar Hauser, a young boy who gradually crosses the border from being a monadic subject to becoming a speaking member of inter-subjective community, Mollenhauer seems to advocate a 'borderline' pedagogic coming from and leading back to human existence as experienced. He cites Wittgenstein, who asserts that "the subject does not belong to the world; rather it is a limit of the world" (as cited in Mollenhauer 2014, p. 60).

If it is true that Mollenhauer's pedagogic and hermeneutic phenomenology commensurate in their shared focus on the concrete situated, singular, irreplaceable human experience, then this experience takes place in the midst of the complexity and paradoxes of our moral-relational world, and pedagogic situations as first premise should be kept open to experiential insight, rather than being educationally effectuated, explained or resolved. Heini and Didier are not learners or educational projects as first premise. They are simply children in need of help to grow up (Langeveld, 1975).

\section{Relational Responsibility for That Which Is}

One basic insight in Mollenhauer's dealings with childhood relationships is that pedagogical responsibility is a responsibility for the unique child and in the same breath a responsibility for one's own adult responsibility. A consequence of this relational responsibility - the relation between the adult and the child, as well as the relation between the adult and him- or herself - has to do with pedagogical responsibility being a response to children's experienced existence, or what he with church-father Augustin refers to as "a response to a call" (Mollenhauer 2014, p. 25). The empirical authenticity of the relational pedagogical experience opens a space for the child's (and the adult's) Bildsamkeit, and a potential understanding of how human subjectivity might be pedagogically nurtured. Biesta (2006, p. 106) in accordance with Mollenhauer and Arendt touches on this same point when he writes: "subjectivity is not a kind of inner self that merely awaits expression". The subjective self can only come into presence in relation to and interdependent of others. In pedagogical settings, only the help of the adult in the culture can realize the pedagogical preparedness of the child. Human subjectivity cannot simply be externally prompted or forced by teachers or educational systems. Rather, there has to be something present in the young person, something that is oriented toward others - asking for help - in order for pedagogic help to be meaningful. Bollnow (1968, p. 21) sees this orientation as a kind of relational readiness that requires a response. The child (or the adult) is not necessarily aware of the child's readiness. Readiness for being taught something from someone is less a question of cognition than of 
pedagogical climate, Bollnow observes. The human condition of being put in a world of plurality and difference (Arendt, 1958), enduringly resists our wish for being masters of what we do. On the contrary, we are relationally reliant and remain beginners in need of others to give us subjective space. Questions of Bildsamkeit thus, are always questions of pedagogical relationality and responsibility for the unique being and becoming of the child in the world. Neither the child nor the adult is outside the world, or one is more in the world than the other - they are in the same world, although in different ways.

Mollenhauer's pedagogical alternatives are not alternatives related to or coming from what ought and should be. Neither are they suggestions of more successful or pedagogically awarding procedures. He claims that the works of Canetti or Pestalozzi and others "don't even worship success as the be-all and end-all" (2014, p. 1). We always are some way or another and our being and acting means something to the child. "There are always alternative ways of acting (and thus thinking) in and about the relation between child and adult, and the alternative is related to what the adult finds important in life directly played out in the concrete relational encounter"(Saevi 2015, p. 7). What then might be Mollenhauer's purpose with the concrete relational examples of potentially failed pedagogical actions from the margins? I think that his aim with the stories is to point to the fact that he considers exactly complex, multi-interpretive and unsuccessful experiences to be at the core of pedagogic. His sketch to a general pedagogic originates and returns continually to human existence and to children's lifeworlds. The experience that what is in pedagogical situations is different from what should have been or ought to be, indicates a basic difference between an existential pedagogic and a psychological, prescriptive foundation for education. Hermeneutic phenomenology, as an existential approach to the human lifeworld (Levering, 2010; Saevi, 2014; van Manen, 2014), is primarily and solely concerned with what a phenomenon is and how it is lived and experientially interpreted by the subject. Mollenhauer, throughout his book, does not present solutions or explanations, but by way of suggestions he attempts to show us what pedagogical situations look like. He describes and interprets what is and hands it over to the reader to understand the pedagogical meaning of and in the situations. He makes descriptive, interpretive sketches of children and adults in relationships, and addresses our pedagogic willingness to do the same in inventive and caring ways to children and young people in our lives.

\section{Endnotes}

i. The English translation is perhaps of necessity less concrete and nuanced than the German original and the Norwegian translation regarding some of this particular excerpt's core pedagogical notions. It is not clear if it is possible at all to preserve those meanings in the English language, but it cannot be denied that the pedagogical meaning is fading here. In the quote above Mollenhauer speaks about "Das elementare Erfahrungsmaterial" (1983, p. 102), the Norwegian translation says "Pedagogikkens elementære erfaringsmateriale" (1996, p. 93) and the English speaks of "The entire enterprise of pedagogy". The term "elementar /elementær refers to what was first; the original, and to what is basic or simple, rather than to the entirety of it, as in the English translation. Another example is the diverging meanings of the terms "wissenschaftlich" / "vitenskapelig" and the English translation "formal scholarly", which of necessity does not suggest the same as a breadth of Wissenschaft (which incorporates both the natural and human sciences). The German and Norwegian languages seem to be more concretely oriented to the inherent meaning of adult responsibility in pedagogic and dare to speak to human experience and to the complexities of practice; while the English may lead one to take a far more intellectual and theoretical stand. 


\section{References}

Arendt, H. (1958). The Human Condition. New York: Doubleday Anchor Books.

Biesta, G. J.J. (2006). Beyond Learning. Democratic education for a human future. Boulder: Paradigm Publishers.

Bollnow, O.F. (1968). Die pädagogische Atmosphäre: Untersuchungen über die gefühlsmässigen zwischenmenschlichen Voraussetzungen der Erziehung. In Anthropologie und Erziehung, 12. Heidelberg: Quelle \& Meyer.

Jegge, J. (1977). Dummheit ist lernbar. Erfahrungen mit “Schulversagern.” Bern, 1976.

Langeveld, M. (1975). Personal help for children growing up. The W.B. Curry Lecture delivered at The University of Exeter on November 8. 1975

Levering B (2010). Phenomenology and Existentialism. In: P. Peterson, E. Baker, B. McGaw, (Eds.). International Encyclopedia of Education, vol.6, pp. 80-85. Oxford: Elsevier.

Lippitz, W. (1986). Understanding children, communicating with children: Approaches to the child within us, before us and with us. Phenomenology + Pedagogy, 4/4, p. 56-65.

Mannoni, M. (1978). Ein Ort zum Leben. Frankfurt.

Mollenhauer, K. (1983). Vergessene Zusammenhänge. Über Kultur und Erziehung. München: Juventa Verlag.

Mollenhauer, K. (1996). Glemte sammenhenger. Om kultur og oppdragelse. Oslo: Ad Notam. (Transl. Stein Wivestad).

Mollenhauer, K. (2014). Forgotten Connections. On Culture and Upbringing. New York: Routledge. (Transl. Norm Friesen).

Saevi, T. (2011). Lived Relationality as Fulcrum for a Pedagogical - Ethical Practice. Studies in Philosophy and Education, Vol. 30, Issue 5 (2011), pp. 455-461.

Saevi, T. (2014). Phenomenology in Educational Research. In L. Meyer (Ed.). Oxford Bibliographies in Education. New York: Oxford University Press.

Saevi, T. (2015). Learning on Pedagogic Relationships. In D. Scott \& E. Hargreaves (Eds.). Handbook of Learning. London: Sage. [forthcoming].

Van Manen, M. (2014). Phenomenology of Practice. Walnut Creek, California: Left Coast Press 